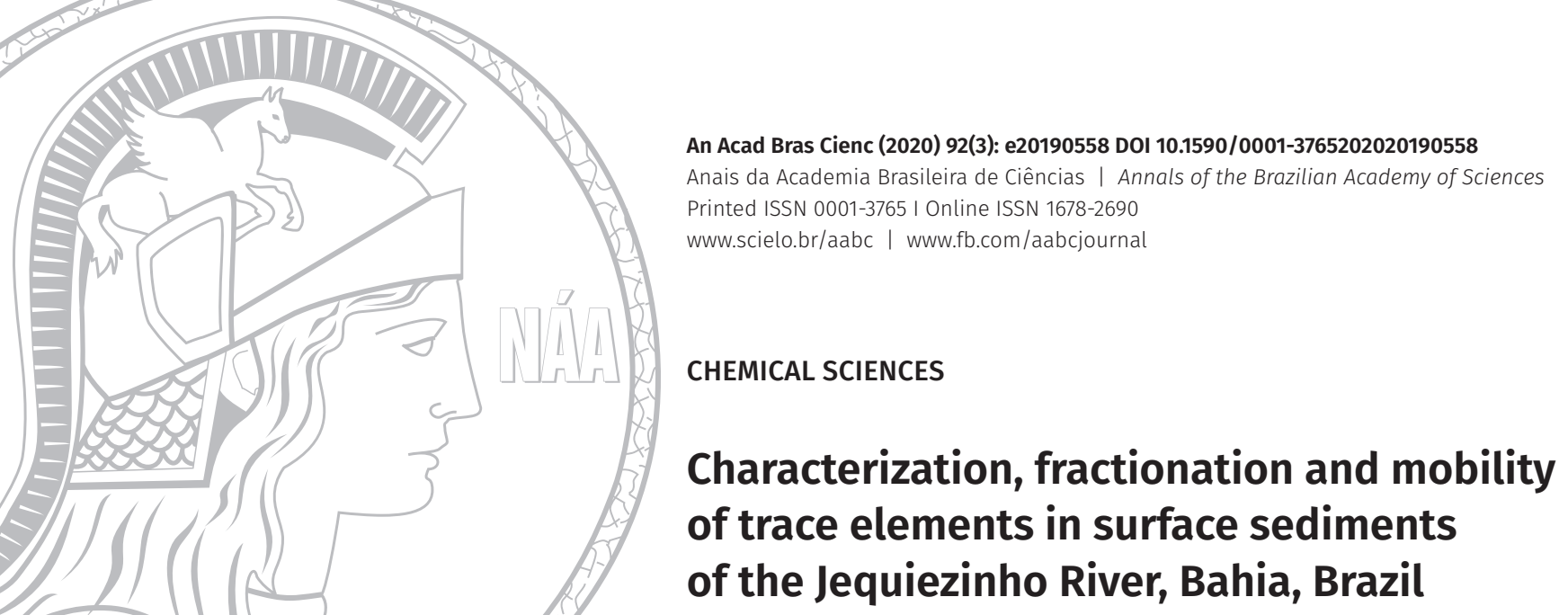

\title{
Characterization, fractionation and mobility of trace elements in surface sediments of the Jequiezinho River, Bahia, Brazil
}

\author{
DARCI S. SILVA, UILLIAN M.F.M. CERQUEIRA, ROSANE M. AGUIAR, \\ PAULO LUIS S. CARNEIRO \& MARCOS A. BEZERRA
}

\begin{abstract}
The Jequiezinho River is a temporary river. In the urban stretch it is impacted, with perennial flow coming from domestic sewage and rainwater. This study evaluated the geochemical distribution and potential mobility of some metals ( $\mathrm{Pb}, \mathrm{Co}, \mathrm{Ca}, \mathrm{Cr}, \mathrm{Mg}$, $\mathrm{Cu}, \mathrm{Fe}, \mathrm{Mn}, \mathrm{Ni}$ and $\mathrm{Zn}$ ) in sediments of the Jequiezinho River. Sediment samples were collected at ten different sites along the river. The silt/clay fraction was submitted to acid digestion and sequential extraction with analysis by FAAS. The results indicated that, in the more densely populated region, there was an increase in concentrations of $\mathrm{Cr}, \mathrm{Ni}, \mathrm{Cu}, \mathrm{Co}, \mathrm{Pb}$, and $\mathrm{Zn}$. The contents found were compared with the guideline values of TEL (Threshold Effect Levels) and PEL (Probable Effect Levels), not exceeding the maximum reference limits. The results indicated that $\mathrm{Ca}, \mathrm{Mg}, \mathrm{Mn}$ and Fe presented greater susceptibility to mobility and bioavailability suggesting the geochemical origin responsible for these high concentrations. The multivariate analysis showed that $\mathrm{Cr}$, $\mathrm{Ni}, \mathrm{Cu}, \mathrm{Co}, \mathrm{Pb}$, and $\mathrm{Zn}$ presented a similar behavior, especially in locations with higher population density and the discharge of non-discriminated effluents, reflecting the anthropogenic contributions as responsible for the concentration increase.
\end{abstract}

Key words: Jequiezinho River, sediments, metals, sequential extraction.

\section{INTRODUCTION}

Sediments are the layers of finely granulated mineral and organic particles that are in contact with the lower parts of natural water bodies, such as lakes, rivers and oceans (Baird \& Cann 2011). Sediments can accumulate large amounts of chemical compounds such as metals, pesticides, polycyclic aromatic hydrocarbons (PAHs) and can consequently be transferred to the living organisms in contact with them. Due to this fact, sediments have been widely used to monitor and track possible sources of environmental contamination, functioning as efficient environmental indicators (Soares et al. 1999, Duodu et al. 2016, Unda-Calvo et al. 2019).
Some elements occur naturally in the soil at concentrations that vary according to their genesis, being classified as micro and macro elements (Resende et al. 1995), which are recognized as essential for life in concentrations adequate for the functioning of biological systems such as Fe, Mg, Ca, Mn and K. However, the increased availability of these elements in the environment, where the concentrations exceed the tolerable limit, lead to serious environmental problems (Silva 2006, Vareda et al. 2019).

Besides being considered water pollutants and food contaminants when in high concentrations, metals can also be transported by air, either as gases or as adsorbed species 
on suspended particulate matter (Baird \& Cann 2011, Zhang et al. 2016). Although most pollutants adsorbed to the sediments are not readily available to aquatic organisms, the variation of some physical and chemical characteristics of water $(\mathrm{pH}$, salinity, redox potential and the content of organic chelates) may lead to the release of metals into the aqueous phase, thus becoming an important pollution source (Soares et al. 1999).

In the sediment, depending on its chemical form, trace elements can exist in various forms. When these compartments do not undergo anthropic action, they are mainly linked to silicates and primary minerals and, therefore, to a low degree of mobility (Pereira et al. 2007). On the other hand, those chemical elements incorporated from anthropic activities are more mobile, associated to the organic matter present in the fine fraction of sediments or adsorbed in hydrated Fe/Mn oxides, or are bound to other phases of the sediment, such as carbonates, oxides, hydroxides and sulfides (Pereira et al. 2007, Kersten \& Förstner 1989).

Sediment samples can be an important tool for assessing the pollution level of a water body (Förstner 2004, Turner \& Taylor 2018). The determination oftrace metals in sediments allows evaluating the level of contamination to which the water is subjected, as well as the present organisms. However, the total concentration does not provide enough data to evaluate contamination, since the present elements, depending on the chemical form, can affect bioavailability, toxicity, chemical interactions and mobility in the environment (Barreto et al. 2004, Morillo et al. 2008, Relic et al. 2010, Alan \& Kara 2019). The study of exchangeable fractions (sequential extraction) can be used for a greater precision on the amount of metals present in the environment that could be mobilized by the chemical changes of the sediment (Adami et al. 1999, Hang et al. 2009, Rosado et al. 2016).

Sequential extraction consists of a variety of techniques widely used for the fractionation of metals in soils, sediments and other environmental matrices. It intends to assess the potential for mobility and availability of these metals in the environment (Gleyzes et al. 2002). The most widely used methods are those based on the multi-step extraction procedure, in which different reagents are consecutively used to extract metals from the fractions operationally defined (Pereira et al. 2007).

The Jequiezinho River is a temporary river that shows water runoff only in the rainy season and complete drought in the absence of rainfall. In the stretch that crosses the urban area of Jequié, it is quite impacted, with a perennial flow coming from the supply of domestic sewage. Studies conducted in the Contas River basin at points sampled near the Jequiezinho River indicate that there is a compromise of water quality in relation to the chemical parameters, very different from the other points along the basin (Dos Santos et al. 2009). This research aimed to evaluate the geochemical distribution and mobility of some metals ( $\mathrm{Cu}, \mathrm{Pb}, \mathrm{Co}, \mathrm{Ni}, \mathrm{Mg}$, $\mathrm{Mn}, \mathrm{Fe}, \mathrm{Zn}, \mathrm{Cr}, \mathrm{Ca}$ ) and their pollution potential in sediments of the Jequiezinho River through a sequential extraction procedure.

\section{MATERIALS AND METHODS}

\section{Study area}

The Jequiezinho River is 58,300 m long and, together with the Pati River and Riacho Conceição, form the Jequiezinho River subbasin (Figure 1). It is born in the municipality of Maracás (Bahia/Brazil) at an altitude of approximately $800 \mathrm{~m}$, passes through the rural region of Lafaiete Coutinho (Bahia/Brazil) and flows into the Contas River in the municipality of 
Jequié (southwestern Bahia/Brazil) (Magalhães et al. 2016).

The urban area of Jequié is densely populated. In its limits, a landfill, roads and a fuel distribution pipeline can be found, generating a large amount of domestic sewage and other non-discriminated pollutants. The predominant climate in this area is typical of semiarid regions, dry most of the time, with periods of rainfall (December to March). The predominant vegetation is the Caatinga (a semiarid vegetation) which, together with the climate and the geomorphology of the region, makes it difficult to store water, giving the river a temporary character, with rainfall and extreme drought during the dry season (Magalhães et al. 2016).
The collection points were chosen strategically, according to the absence or presence of potential pollution sources, such as agricultural properties, landfills, fuel distributors, and domestic sewage. Points from rural zone, considered as non-impacted, were also collected, aiming to make comparisons. The collection sites were georeferenced using a GPS (Global Positioning System) (Table I).

\section{Sample collection}

Samples were collected in two campaigns, the first in March/2018 (late rainy season) and the second in September/2018 (dry season). Ten samples were collected in each period at different points along the Jequiezinho River, comprising rural and urban areas.

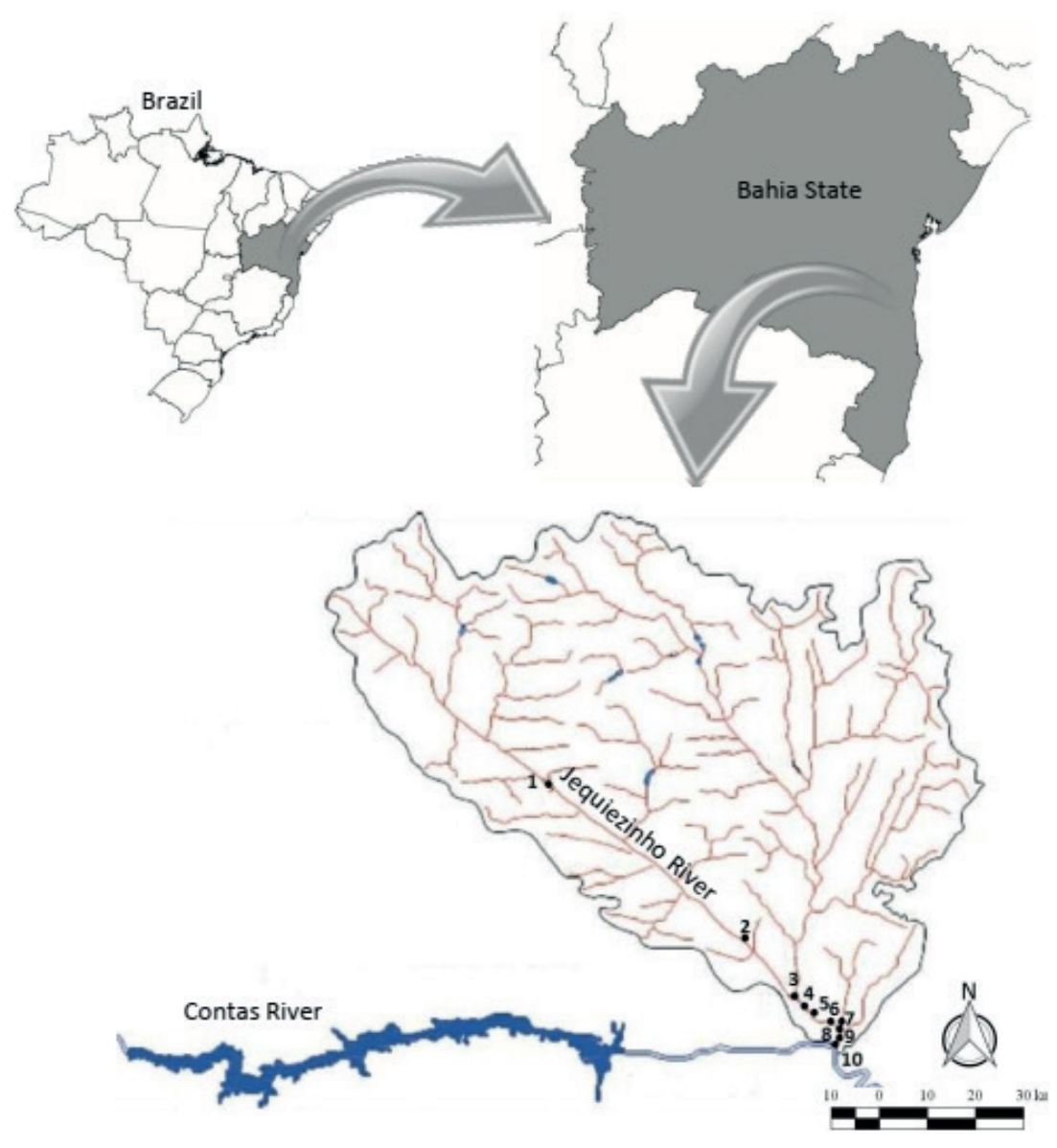

Figure 1. Sub-basin of the Jequiezinho River. Adapted from Magalhães et al. 2016. 
Sampling was performed by removing approximately $2.0 \mathrm{~kg}$ of sediment from the superficial layer of the sediment (0-5 cm deep), discarding leaves and other surface materials at a distance of approximately 2.0 meters from the edge, using a polyethylene spatula; the material was then packed in sterile plastic bags, sealed and stored in a refrigerator at $5{ }^{\circ} \mathrm{C}$ until laboratory processing.

Seasonal variation is one of the main factors responsible for the dynamics of chemical species in aquatic environments, where irregular rainfall distribution may influence their mobility. Rainfall analysis for the region allowed characterizing two periods: rainy (Nov/2017 to Feb/2018) and dry season (April to October 2018) (Figure 2), and this criterion was used to schedule the collection of sediment samples.
During the whole study period, the water volume showed a strong climatic irregularity, with a deficit occurring in all the months of 2018. The collection made in March 2018 occurred in places with some volume of water, except in P2. On the other hand, in the second collection, the sampling points P1 to P4 had dried and the other points contained a small water flow, coming only from the discharge of sewage.

\section{Cleaning/material decontamination}

All glassware, spatulas and polyethylene bottles were washed with neutral detergent and rinsed in running water until the product was completely removed. They were then immersed in 10\% $\mathrm{HNO}_{3}$ solution (v/v) for 24 hours and rinsed with deionized water for 3 (three) times, oven dried at $60{ }^{\circ} \mathrm{C}$ (glassware) or at room temperature

Table I. Location/characterization of collection points of sediments.

\begin{tabular}{|c|c|c|c|c|}
\hline Point & Description & Area type & Coordinates & Altitude (m) \\
\hline P1 & Farm in Lafaiete Coutinho & Rural & $\begin{array}{c}\text { S13.66675 } \\
\text { W040.29587 }\end{array}$ & 473 \\
\hline P2 & Farm in Jequié & Rural & $\begin{array}{l}\text { S13.81686 } \\
\text { W040.11827 }\end{array}$ & 215 \\
\hline P3 & Next to a landifill & Rural & $\begin{array}{c}\mathrm{S} 13.82511^{\circ} \\
\text { W040.11406 }\end{array}$ & 210 \\
\hline P4 & $\begin{array}{c}\text { Residences, corrals, rainwater } \\
\text { drainage }\end{array}$ & Urban & $\begin{array}{l}\mathrm{S} 13.82904^{\circ} \\
\mathrm{W} 040.10888^{\circ}\end{array}$ & 208 \\
\hline P5 & Bridge on the BR 116 highway & Urban & $\begin{array}{l}\mathrm{S} 13.83294^{\circ} \\
\text { W040.10407º }\end{array}$ & 206 \\
\hline P6 & Bridge on a side road & Urban & $\begin{array}{l}\mathrm{S} 13.83688^{\circ} \\
\mathrm{W} 040.09901^{\circ}\end{array}$ & 204 \\
\hline P7 & Next to a fuel pipeline distributor & Urban & $\begin{array}{l}\mathrm{S} 13.84860^{\circ} \\
\mathrm{W} 040.07506^{\circ}\end{array}$ & 182 \\
\hline P8 & Residences, rainwater drainage & Urban & $\begin{array}{c}\mathrm{S} 13.86121^{\circ} \\
\mathrm{W} 040.07612^{\circ}\end{array}$ & 180 \\
\hline P9 & Residences, rainwater drainage & Urban & $\begin{array}{c}\text { S13.86414 } \\
\text { W040.07737 }\end{array}$ & 180 \\
\hline P10 & $\begin{array}{c}\text { Confluence Jequiezinho River and } \\
\text { Contas River }\end{array}$ & Urban & $\begin{array}{l}S 13.866089^{\circ} \\
W 40.078423^{\circ}\end{array}$ & 178 \\
\hline
\end{tabular}




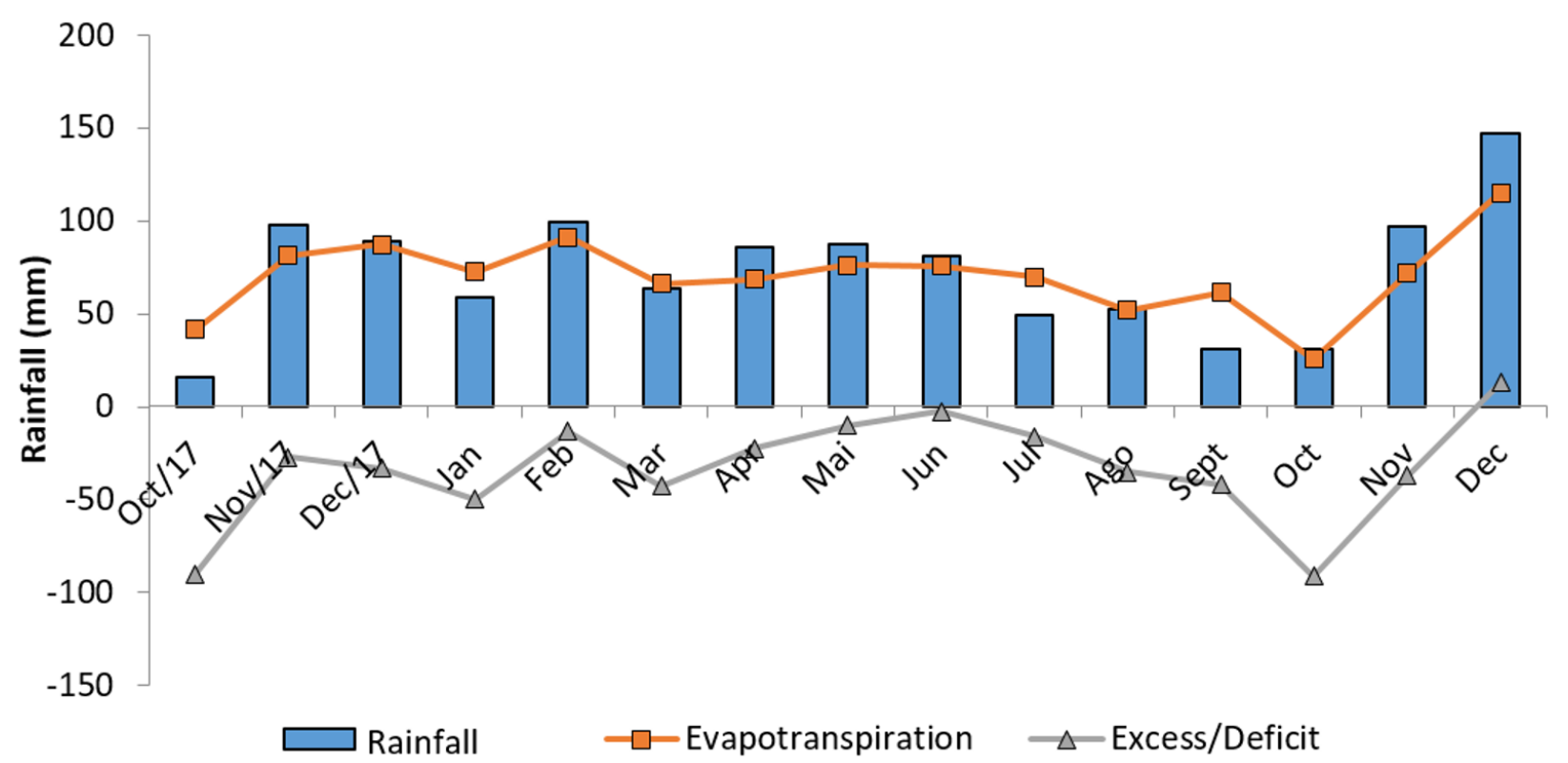

Figure 2. Water balance from January to December 2018, in the municipality of Jequié. Source: CPTEC INPE: http:// www.cptec.inpe.Br/proclima2/balanço_hidrico/balancohidrico. shtml. Accessed on 05/05/19.

(other materials) and packed in boxes in order to preserve the decontaminated material.

\section{Sample treatment}

The sediment samples were oven dried at $60^{\circ} \mathrm{C}$ for 24 hours. Subsequently, each sample was triturated with mortar and pistil, sieved in 250$\mu \mathrm{m}$ mesh, transferred to decontaminated plastic bottles and sealed.

Pseudo-total digestion was based on the study of McGrath et al. (1985), using a mixture of $5.0 \mathrm{~mL}$ aqua regia $\left(\mathrm{HCl}\right.$ p.a. $+\mathrm{HNO}_{3}$ p.a. 3:1 v/v) for a mass of $0.5 \mathrm{~g}$ of sediment sample. Initially, the digestion occurred at room temperature for 16 hours and then heated in a digestion block at a temperature of $(90 \pm 5){ }^{\circ} \mathrm{C}$ with the tubes partially capped until the $\mathrm{NO}_{2}$ release ceased. After this step, the samples were cooled, filtered and transferred to polyethylene bottles, set to 10 $\mathrm{mL}$ with deionized water, kept under refrigeration at $4^{\circ} \mathrm{C}$ until metal determination. The accuracy of this decomposition method was evaluated by analysis of a certified reference material (NIST 1646a - Estuarine sediments).
The methodology used for fractionation by chemical extraction was based on Tessier et al. (1979), and consists of four fractionation stages. For each step, an aliquot with $1.0 \mathrm{~g}$ of dry sediment was added to a glass vessel along with the respective reagents, according to the protocol defined for each fraction (Table II). Finally, the suspension was filtered, set to $25 \mathrm{~mL}$ with deionized water, transferred to a polypropylene tube, and stored at $4^{\circ} \mathrm{C}$ until metal determination.

All samples used in both pseudo-total and fractional extraction were analyzed in triplicate. The blank of the digestion procedure, containing all reagents except the sample, was prepared and treated under the same procedure described for the sediment samples.

\section{Instrumentation}

For the pseudo-total digestion procedure of the sediment samples, glass tubes with reflux system (cold finger) heated in a microprocessed digital digestion block (TECNAL, TE-007MP) were used. In sequential extraction, 250-mL Erlenmeyer 
Table II. Procedures following each step of sequential extraction.

\begin{tabular}{|c|c|c|c|}
\hline Fraction & Reagents & Final volume $(\mathrm{mL})$ & Experimental conditions \\
\hline Soluble & Deionized water & 25 & $\begin{array}{l}1 \mathrm{~h} \text {, room temperature, continuous } \\
\text { stirring }\end{array}$ \\
\hline Ion-changed & Ammonium acetate & 25 & $\begin{array}{l}1 \mathrm{~h} \text {, room temperature, continuous } \\
\text { stirring }\end{array}$ \\
\hline Carbonate bounded & Acetate buffer & 25 & $\begin{array}{c}5 \mathrm{~h} \text {, room temperature, continuous } \\
\text { stirring }\end{array}$ \\
\hline $\begin{array}{c}\text { Organic matter } \\
\text { bounded }\end{array}$ & $\mathrm{H}_{2} \mathrm{O}_{2} 30 \% / \mathrm{HNO}_{3}$ & 25 & $5 \mathrm{~h}, 85^{\circ} \mathrm{C} \pm 2$, periodic stirring \\
\hline
\end{tabular}

were used in a horizontal shaker with a capacity of 16 flasks (Ethik Technology).

The analysis of $\mathrm{Fe}, \mathrm{Zn}, \mathrm{Mn}, \mathrm{Ca}, \mathrm{Mg}, \mathrm{Pb}, \mathrm{Co}$, $\mathrm{Cu}, \mathrm{Ni}$ and $\mathrm{Cr}$ was performed on a flame atomic absorption spectrometer (AAnalyst 200, PerkinElmer) fed with an air/acetylene mixture. Hollow cathode lamps of the respective metals were used as a radiation source. The wavelengths used were those recommended by the manufacture for Ca (422.7 nm), Cu (324.8 nm), Fe (248.3 nm), Mn (279.5 nm), Ni (232.0 nm), Zn (213, 9 nm), Pb (283.3 nm), Co (240.7 nm) Cr (357.9 nm) and Mg (285.2 $\mathrm{nm}$ ) determination. The other operating conditions of the equipment were acetylene flow rate $\left(2.0 \mathrm{~L} \mathrm{~min}^{-1}\right)$, air flow rate $\left(13.5 \mathrm{~L} \mathrm{~min}^{-1}\right)$ and solution aspiration flow rate $\left(5.0 \mathrm{~mL} \mathrm{~min}^{-1}\right)$.

\section{Statistical analysis}

Principal component analysis (PCA) was used to evidence possible similarities among the samples and variables and to estimate the potential sources of contamination. Pearson's correlation analysis was used to determine the relationship between the metals studied. Hierarchical cluster analysis (HCA) was performed in a complementary manner to PCA to confirm the results and provide grouping of variables. The grouping method used was the
Ward's Method, due to its capacity to produce a well-defined dendrogram.

\section{RESULTS AND DISCUSSION}

\section{Total contents and metal fractionation}

Sample digestion using aqua regia is strong enough to provide most of the elements to the solution, but it does not constitute a total digestion and therefore represents the "pseudototal" concentration of these elements. This type of digestion provides, in addition to more labile metals, those of lower mobility that are associated with the crystalline oxides of iron and manganese, organic matter, sulfides and some more altered silicates (Ryan et al. 2002). Although not all the elements that comprise the sediment are available for analysis, the results obtained are sufficient to quantify the metals in the sediment, and this method is widely used in studies on chemical composition in environmental matrices.

\section{Quantification and evaluation of the behavior of metals in the Jequiezinho River}

The elements $\mathrm{Fe}, \mathrm{Mg}$ and $\mathrm{Ca}$ are present in the sediments at the highest concentrations (on average: $19479.24,1590.35$ and $1377.77 \mathrm{mg} / \mathrm{kg}$, respectively), while the other elements had lower 
values, especially Co, which presented the lowest average $(11.41 \mathrm{mg} / \mathrm{Kg})$ in relation to the samples collected in the first campaign (Table III). In the samples collected in the second campaign, the elements presented a behavior similar to that of the previous campaign, between average concentrations in all the points sampled. The only exception was $\mathrm{Mg}$, whose values were lower than those of Ca.

\section{Sediment quality guidelines}

The reference values for the evaluation of the quality of the sediments come from data in the literature. The suggested limits are derived

Table III. Descriptive statistics of metal concentrations by pseudo-total digestion in sediment samples from the Jequiezinho River.

\begin{tabular}{|c|c|c|c|c|}
\hline & Average (mg/Kg) & $\begin{array}{l}\text { Lowest value } \\
\text { (mg/Kg) }\end{array}$ & Highest value (mg/Kg) & SD* \\
\hline \multicolumn{5}{|c|}{ End of the rainy season } \\
\hline $\mathrm{Pb}$ & 25.21 & 17.69 (P3) & $38.99(P 8)$ & 6.60 \\
\hline $\mathrm{Cu}$ & 16.68 & $5.491(P 4)$ & 40.92 (P8) & 12.2 \\
\hline Co & 11.41 & $6.832($ P3) & $19.67(\mathrm{P} 5)$ & 3.86 \\
\hline $\mathrm{Cr}$ & 31.90 & $16.58(\mathrm{P} 3)$ & $50.90(P 5)$ & 11.8 \\
\hline $\mathrm{Ni}$ & 20.10 & $10.62(\mathrm{P} 1)$ & 31.10 (P8) & 8.11 \\
\hline Mg & 1590 & $84.43(\mathrm{P} 1)$ & 3500.02(P8) & 1022 \\
\hline$M n$ & 291.6 & $62.11(P 5)$ & $1033.14(P 3)$ & 279 \\
\hline $\mathrm{Ca}$ & 1378 & $49.66(P 4)$ & $8631.70(P 8)$ & 2755 \\
\hline Zn & 48.98 & $15.52(P 8)$ & $132.11(P 5)$ & 32.64 \\
\hline $\mathrm{Fe}$ & $1.948 \times 10^{4}$ & $1.178 \times 10^{4}(\mathrm{P9})$ & $27862.82(P 5)$ & 4611 \\
\hline \multicolumn{5}{|c|}{ Dry season } \\
\hline $\mathrm{Pb}$ & 22.20 & $12.77(\mathrm{P} 10)$ & $36.73(P 4)$ & 7.30 \\
\hline $\mathrm{Cu}$ & 15.88 & 4.092 (P5) & $45.10(P 4)$ & 12.3 \\
\hline Co & 8.931 & $3.903(\mathrm{P} 5)$ & $16.59(\mathrm{P} 4)$ & 4.17 \\
\hline $\mathrm{Cr}$ & 28.67 & 14.86 (P10) & $51.02(P 7)$ & 12.4 \\
\hline $\mathrm{Ni}$ & 19.33 & $9.54(\mathrm{P} 1)$ & $35.28(P 7)$ & 7.84 \\
\hline Mg & 1607 & $326.2(\mathrm{P} 1)$ & 2993 (P3) & 945 \\
\hline $\mathrm{Mn}$ & 215.1 & $109.3(P 4)$ & 346.8 (P6) & 78.4 \\
\hline $\mathrm{Ca}$ & 2466 & $99.39(\mathrm{P} 1)$ & $7780(P 9)$ & 2940 \\
\hline $\mathrm{Zn}$ & 55.66 & $23.96(P 5)$ & $99.38(P 4)$ & 22.7 \\
\hline $\mathrm{Fe}$ & $1.544 \times 10^{4}$ & 8334 (P10) & $2.413 \times 10^{4}(\mathrm{P} 7)$ & 5336 \\
\hline
\end{tabular}

*Standard deviation. 
from the contamination database and define the ranges between which relationships are established to various biological effects. In Brazil, the legal instrument that regulates sediment quality is CONAMA (Conselho Nacional do Meio Ambiente), Resolution 454/2012, which regulates the dredging and disposal of dredged sediments. The guiding values adopted in this document refer to official Canadian, North American and European publications.

In this study, the metal concentrations of the Jequiezinho River sediments were compared to the values of TEL (Threshold Effect Levels), that is, limit levels of effect on organisms and PEL (Probable Effect Levels) of probable adverse effects on organisms, established by the National Oceanic Atmospheric Administration (NOAA) (Table IV).

Results of the pseudo-total digestion are shown in Figure 3. It is noted that $\mathrm{Cr}$ contents were quite uniform at the points sampled for the two campaigns, with P4, P5, P7 and P8 showing values higher than the reference level (37.3 mg / kg) established by CONAMA. Nickel concentrations were also higher than the reference value (35.9 $\mathrm{mg} / \mathrm{Kg}$ ), except for P1 and P3. The points located in the urban area, especially $\mathrm{P7}$, presented values close to the maximum predicted by the environmental legislation (35.9 mg/ Kg).

Copper also had concentrations above level 1 at P4, P5 and P8 (37.7 mg/ Kg), with a small seasonal variation. Lead did not exceed the limits in P1 to P3, P6 and P9, suggesting a low probability of adverse effects to the biological community. However, at P4, P5 and P8, the concentrations exceeded reference level 1 (35.0 $\mathrm{mg} / \mathrm{Kg}$ ). This increase found in the urban area of Jequié can be attributed to greater population density and the discharge of sewage directly into the river. $\mathrm{Zn}$ did not show high concentrations at most of the sample points, except for P5 which, at the first sampling (end of the rainy season), showed a significant concentration above reference level 1 (123 $\mathrm{mg} / \mathrm{Kg})$.

For Co, Fe, Ca, Mn and $\mathrm{Mg}$, there are no boundary values in the Brazilian legislation for sediments. However, the presence of these metals in the environment can not always be attributed to anthropogenic action. These elements can also be made available through natural rock decomposition processes, which constitute the geology of the region, so the increase in the concentrations can be due to the transport of soil particles.

The results obtained for the samples in the two campaigns indicate that the elements $\mathrm{Fe}, \mathrm{Ca}, \mathrm{Mg}$ and $\mathrm{Mn}$ presented the highest concentrations for the pseudo-digestion of all sampling points, with Fe was the one with the highest concentrations. According to Ure et al. (1993), these elements tend to be present in large quantities in the soil, since they participate in the formation of the Earth's crust and can be seen as essentially lithogenic metals. However, although the others present relatively smaller values, they may be related to potential anthropogenic environments (Fernandes 1997).

A similar behavior for these elements was found by Correia (2014) in Contas sediments, where it was observed that Fe also presented

Table IV. Reference values in dry matter (mg/Kg), classification levels according to CONAMA 454/2012 and sediment quality guide values expressed as TEL (level 1) and PEL (level 2).

\begin{tabular}{|c|c|c|c|c|c|c|c|c|c|c|}
\hline Reference values & Cu & Co & Cr & Pb & Zn & Ni & Fe & Ca & Mn & Mg \\
\hline Level $1(\mathrm{mg} / \mathrm{kg})$ & 35.7 & - & 37.3 & 35 & 123 & 18 & - & - & - & - \\
\hline Level 2 $(\mathrm{mg} / \mathrm{kg})$ & 197 & - & 90 & 91.3 & 315 & 35.9 & - & - & - & - \\
\hline
\end{tabular}



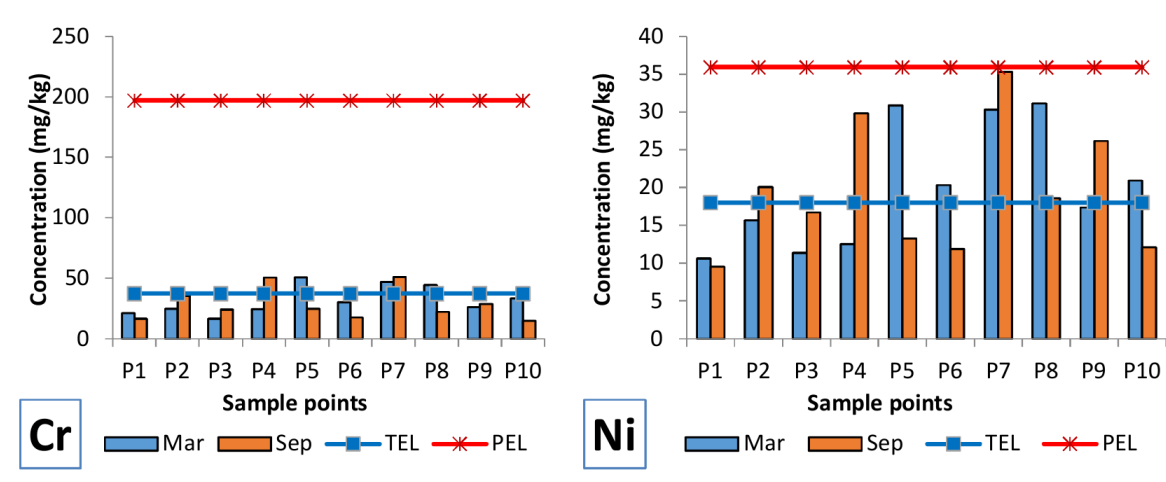

Figure 3. Comparison of $\mathrm{Cr}, \mathrm{Ni}, \mathrm{Cu}, \mathrm{Pb}$ and $\mathrm{Zn}$ concentrations in sediments of the Jequiezinho River with Canadian guideline values (TEL/PEL).
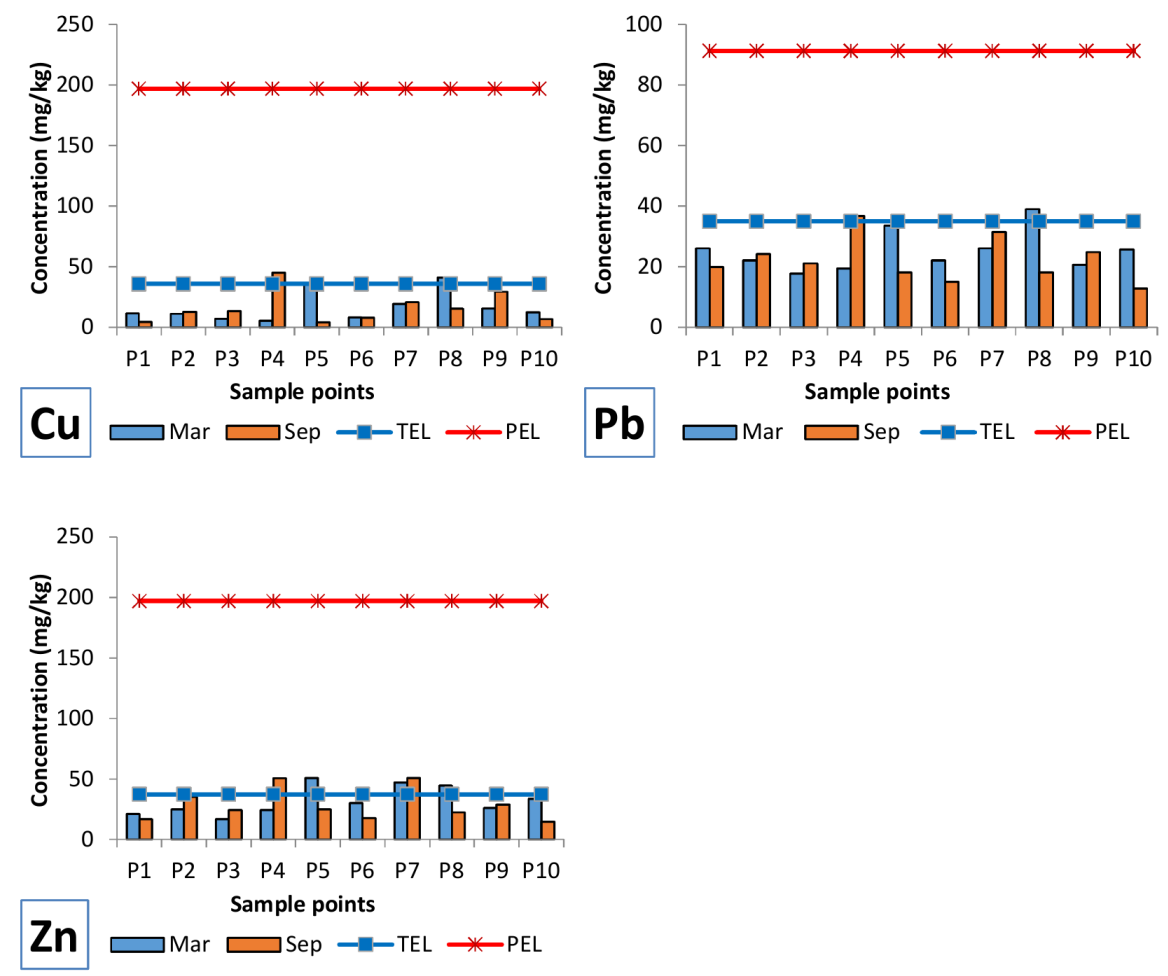

high values. A study by Santos et al. (2007) concluded that the high concentrations of calcium found in the Pedras Dam, located in the Contas River, is due to the local geochemical composition. According to Fornari \& Barbosa (1994), this region is located on a granulitic block called Jequié Complex, in which iron formations and quartzites predominate, justifying the presence of these metals in the environmental samples.

The correlation matrix formed by the metal concentrations in the sediment samples in the rainy season (Table $\mathrm{V}$ ) indicates a significant correlation of $\mathrm{Cr}$ with $\mathrm{Ni}, \mathrm{Cu}, \mathrm{Co}$ and $\mathrm{Pb}$, Ni with $\mathrm{Cu}, \mathrm{Cu}$ with $\mathrm{Pb}$ and $\mathrm{Mg}$ with $\mathrm{Ca}$. For the samples collected in the dry season (Table $\mathrm{V}$ ), the high correlations between $\mathrm{Cr}$ and $\mathrm{Ni}, \mathrm{Co}, \mathrm{Pb}, \mathrm{Cu}$ and $\mathrm{Zn}$, and $\mathrm{Co}$ with $\mathrm{Pb}$ and $\mathrm{Fe}$ are highlighted.

Principal component analysis (PCA) in the samples collected for the two periods revealed two main components that, together, account for $79.23 \%$ of the total data variance (Figure 4 ).

PC1 contributed with $58.06 \%$ of the total variance of the metal levels between the 
Table V. Correlation matrix of the pseudo-total metal concentrations in sediments of the Jequiezinho River in (a) March 2018 and (b) September 2018 (in bold, significant correlation $p<0.05$ ).

\begin{tabular}{|c|c|c|c|c|c|c|c|c|c|c|}
\hline & $\mathrm{Cr}$ & $\mathrm{Ni}$ & $\mathrm{Cu}$ & Co & $\mathbf{P b}$ & Mn & Mg & $\mathrm{Fe}$ & $\mathrm{Ca}$ & $\mathrm{Zn}$ \\
\hline \multicolumn{11}{|c|}{ End of the rainy season } \\
\hline $\mathrm{Cr}$ & 1.00 & & & & & & & & & \\
\hline $\mathrm{Ni}$ & 0.98 & 1.00 & & & & & & & & \\
\hline $\mathrm{Cu}$ & 0.81 & 0.83 & 1.00 & & & & & & & \\
\hline Co & 0.80 & 0.72 & 0.74 & 1.00 & & & & & & \\
\hline $\mathbf{P b}$ & 0.78 & 0.78 & 0.94 & 0.78 & 1.00 & & & & & \\
\hline Mn & -0.63 & -0.58 & -0.44 & -0.46 & -0.49 & 1.00 & & & & \\
\hline Mg & 0.60 & 0.73 & 0.70 & 0.18 & 0.60 & -0.44 & 1.00 & & & \\
\hline $\mathrm{Fe}$ & 0.42 & 0.24 & 0.29 & 0.78 & 0.45 & -0.25 & -0.37 & 1.00 & & \\
\hline $\mathrm{Ca}$ & 0.32 & 0.44 & 0.68 & 0.08 & 0.63 & -0.25 & 0.85 & -0.34 & 1.00 & \\
\hline $\mathrm{Zn}$ & 0.57 & 0.44 & 0.39 & 0.78 & 0.31 & -0.24 & -0.15 & 0.70 & -0.37 & 1.00 \\
\hline \multicolumn{11}{|c|}{ Dry season } \\
\hline $\mathrm{Cr}$ & 1.00 & & & & & & & & & \\
\hline $\mathrm{Ni}$ & 0.92 & 1.00 & & & & & & & & \\
\hline $\mathrm{Cu}$ & 0.75 & 0.79 & 1.00 & & & & & & & \\
\hline Co & 0.91 & 0.86 & 0.82 & 1.00 & & & & & & \\
\hline $\mathbf{P b}$ & 0.94 & 0.87 & 0.84 & 0.96 & 1.00 & & & & & \\
\hline $\mathrm{Mn}$ & -0.28 & -0.37 & -0.60 & -0.31 & -0.34 & 1.00 & & & & \\
\hline Mg & 0.21 & 0.51 & 0.29 & 0.27 & 0.18 & -0.36 & 1.00 & & & \\
\hline $\mathrm{Fe}$ & 0.80 & 0.69 & 0.53 & 0.90 & 0.87 & -0.07 & 0.10 & 1.00 & & \\
\hline $\mathrm{Ca}$ & -0.38 & -0.05 & 0.05 & -0.34 & -0.38 & -0.36 & 0.36 & -0.57 & 1.00 & \\
\hline $\mathrm{Zn}$ & 0.72 & 0.84 & 0.96 & 0.80 & 0.79 & -0.55 & 0.46 & 0.51 & 0.17 & 1.00 \\
\hline
\end{tabular}

sampling points, presenting the most significant values for $\mathrm{Cr}, \mathrm{Ni}, \mathrm{Cu}, \mathrm{Co}, \mathrm{Pb}$, Fe and $\mathrm{Zn}$. The metal distribution in $\mathrm{PC1}$ associated the points located in the urban portion of the Jequiezinho River, considered as the most impacted portion of the studied environment, due to the contribution of sewage and other pollutants. This suggests that anthropogenic actions may somehow contribute to increased contamination by these metals. The formation of groups in relation to the collection periods (seasonality) was not observed, evidencing that the temporal conditions in the year 2018 did not significantly influence the quantification of these elements in the analyzed samples, probably due to the water deficit recorded over the study period, as previously shown. 


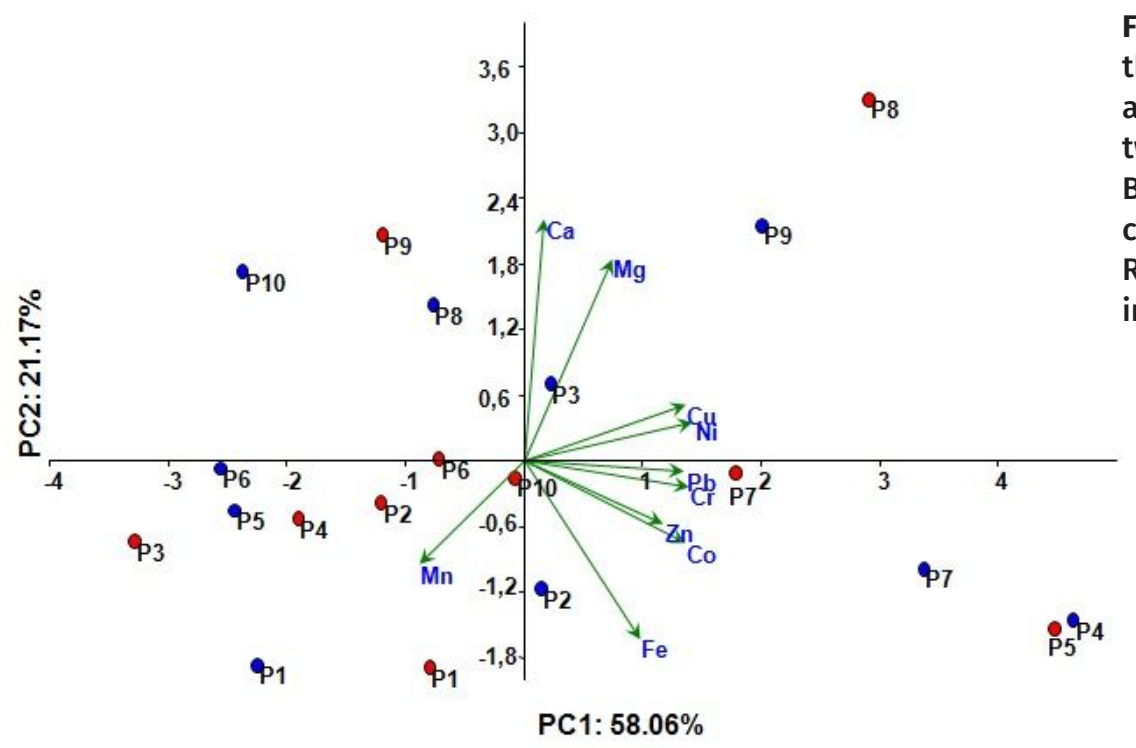

Figure 4. Bi-plot obtained by the overlapping of the scores and loadings graphs for the two sampling campaigns. Blue points: samples collected in the dry season. Red points: samples collected in the rainy season.
PC2 represented $21.17 \%$ of the total variance, with significant loads for $\mathrm{Ca}$ and $\mathrm{Mg}$. These two elements, together with $\mathrm{Fe}$, are considered abundant in the Earth's crust and are majorities in this study. Soil and sediment studies have used these elements as a reference geochemical element in the determination of the geochemical background to evaluate the geoaccumulation index. The analysis of PC2, therefore, accounts for the geochemical contribution to the concentrations of these elements.

The data were classified through hierarchical cluster analysis (HCA), and a double dendrogram was created from the metal concentration in relation to the sampling points. The horizontal dendrogram shows the clustering of the sampling sites (P1-P10), according to metal concentration. In the first sampling period, the points were separated into three major groups (Figure 5a). The first group was formed by the points P1-P4, P6, P9 and P10, which were responsible for the lowest concentrations of the studied metals, located in the area of lower population density, except for P9 and P10. The second group was formed by P5 and P7, as a function of the high concentrations of $\mathrm{Ni}$ and $\mathrm{Cr}$ and, finally, the third group containing only $\mathrm{P} 8$ related mainly to $\mathrm{Ca}$ and $\mathrm{Mg}$ contents.

The results of HCA are consistent with those of PCA, since they demonstrate a tendency of the samples to be grouped according to the collection site. The points located in the urban perimeter were those with the highest metal concentrations, in view of the population density and the release of effluents, which contribute as diffuse metal sources in the sediment.

The vertical dendrogram represents the results of the cluster analysis of the studied metals as a function of their concentration, according to the average Euclidean distances, demonstrating that they can be grouped into three distinct groups. The first group demonstrates that the $\mathrm{Pb}, \mathrm{Cu}, \mathrm{Ca}, \mathrm{Mg}, \mathrm{Ni}$ and $\mathrm{Cr}$ may exhibit similar behavior and geochemical origin, since their concentrations were increased in the most environmentally impacted locations. The second grouping was formed by Co, Fe and $\mathrm{Zn}$, and $\mathrm{Co}$ and $\mathrm{Zn}$ correlated significantly with $\mathrm{Fe}$, suggesting that they tend to concentrate on Fe oxides and hydroxides, corroborating the results of the correlation analysis. However, Mn showed no correlation with any other metal, 

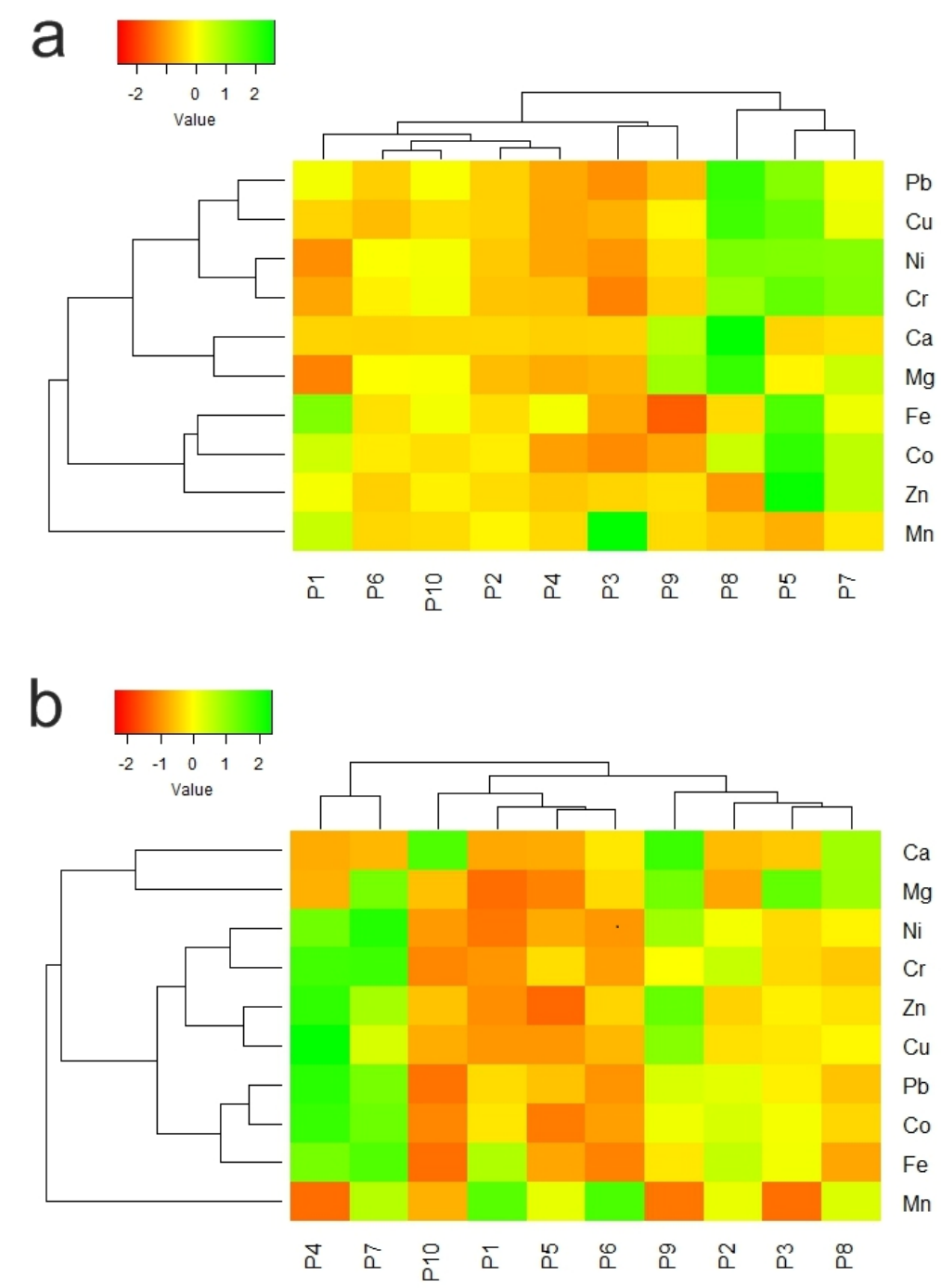

\author{
Figure 5. Results of the \\ heat map for HCA from the \\ concentration of the metals \\ obtained by pseudo-total \\ digestion in sediment samples \\ of the Jequiezinho River (a) first \\ campaign, (b) second campaign.
}

being isolated in the composition of the third grouping.

In the second collection period (Figure 5b), a behavior similar to the first was observed, where the sampling points of the urban area also presented the highest concentrations. The clusters formed by the metals indicate that they may have originated from similar sources, although the anthropogenic contribution on the concentrations presented is evident. The points P2, P3, P8 and P9 were responsible for the formation of the first group, P1, P5, P6 and P10 represented the second group due to the lower metal contents, except for $\mathrm{Mn}$ and $\mathrm{Ca}$ ( $\mathrm{P} 4$ and P7), especially for $\mathrm{Ni}, \mathrm{Cr}, \mathrm{Zn}, \mathrm{Pb}, \mathrm{Co}$ and Fe.
Some studies indicate that $\mathrm{Pb}, \mathrm{Zn}, \mathrm{As}$ and $\mathrm{Cd}$ have the source of anthropogenic factors, such as emissions of exhaust from vehicles, disposal of household waste, application of phosphate fertilizers and pesticides, among others. (Shan et al. 2010, Ungureanu et al. 2016, Guan et al. 2018). The similarity between the collection periods (absence of effects related to seasonality) can be attributed to the water deficit observed in the region for the entire year of 2018, where the physical, chemical and biological processes responsible for the mobility of the chemical species did not change significantly, since the presence of water is critically important for the operation of this system. 


\section{Sequential metal extraction}

The study of chemical species fractionation allowed evaluating which element presented greater mobility potential among the analyzed fractions. According to Copaja et al. (2014), the distribution of trace elements through the different fractions of the sequential extraction procedure allows a better understanding of the bioavailability potential of these elements.

In general, the chemical elements extracted at each fractionation stage at the sampled sites showed similar behavior (Figures 6, 7), and the carbonate fraction was the most expressive; the soluble fraction had few contributions. The fraction of greater environmental interest (labile) presented poor results for most of the elements, except for Fe at the end of the rainy period and for $\mathrm{Fe}$ and $\mathrm{Mg}$ in the samples collected during the dry period.

In the first sample, Fe presented high percentages in fraction 1 (soluble fraction) for most of the sampling points, except in P8 and P9, where fraction 3 (metals bound to carbonates) had a higher value. In the second campaign, Fe presented a similar behavior, also extracted in the soluble and carbonate fractions.

Although $\mathrm{Pb}, \mathrm{Cu}$ and $\mathrm{Cr}$ showed significant concentrations in the pseudo-total digestion, they did not appear in the fractions extracted sequentially, only $\mathrm{Cr}$ in F3 and F4 in the late rainy period and $\mathrm{Cu}$ in $\mathrm{F} 3$ in the second period, being considered of low geochemical mobility. Of all the elements evaluated, $\mathrm{Mn}$ is the most homogeneously distributed among all the fractions extracted. The concentration of $\mathrm{Mn}$ in the available fractions and mainly in the carbonate phase confirmed its high mobility potential, which does not necessarily mean that it is due to anthropogenic contributions, but it may also be due to the geochemical formation of the environment. The geochemical distribution of this element, concentrated in the carbonaceous phase, followed by the reducible one, was verified in other studies involving sediments where sequential extraction was applied (Teixeira et al. 1997, Kersten et al. 1995).

Zinc presented an association with the carbonate fraction for most of the collected samples, except for P7 (March/2018) and P1 (September/2018), with the highest concentrations recorded in the points located in the urban zone. This increase can be caused by the inflow of sewage into the river bed.

The concentration of $\mathrm{Ni}$ in the carbonate fraction did not show significant variations in any of the campaigns carried out. Considering that the values found in samples from rural areas, where anthropic sources are rare, are close to those determined in the urban area, it may be an indicative of the natural origin of this element.

Calcium and $\mathrm{Mg}$ are very abundant in aquatic environments. They participate in the formation of rocks and are released by weathering. Concentrations of $\mathrm{Ca}$ and $\mathrm{Mg}$ had a similar behavior in the samples collected in March 2018, especially in fractions 2 and 4. In the dry season, Mg was not significant in fraction 4, but presented significant values for fraction 1 . Cobalt behavior in the two campaigns was very similar in relation to the extracted fractions, predominating in fraction 3. The occurrence of Co in mafic and granitic rocks mainly suggests that the contents found in the samples probably derive from the geochemical composition of the studied environment.

\section{Environmental implications and metal mobility}

The metals associated with the potentially available fractions (F1 and F2) can be easily mobilized into the environment due to constant changes in physical and chemical parameters such as pH and temperature. Exchangeable, more labile fractions, are generally considered 


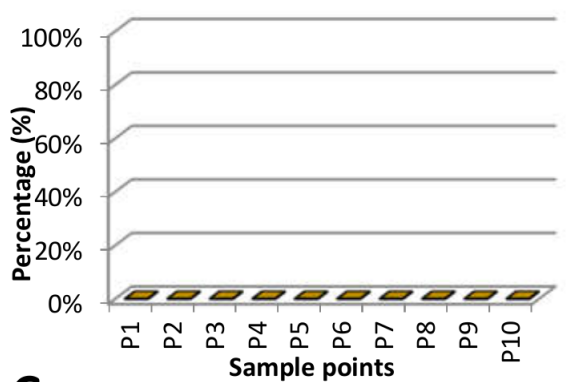

Cu $\quad \begin{gathered}\text { Sample points } \\ \text { CF2 }\end{gathered}$

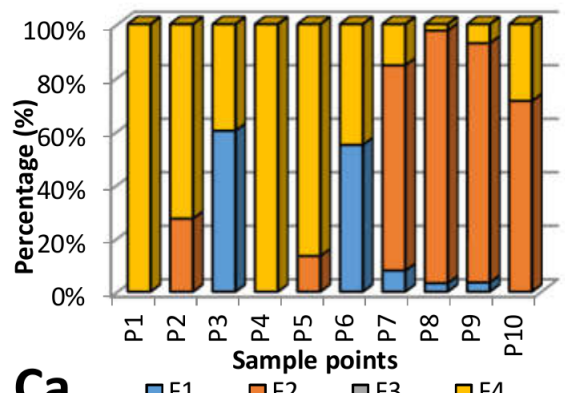

Ca af1 $\begin{gathered}\text { Sample points } \\ \text { CF }\end{gathered}$

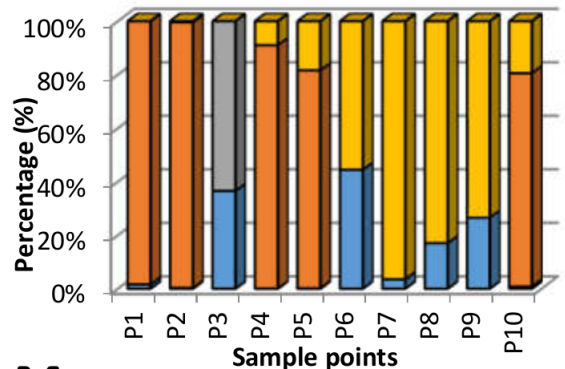

Mg af1 $\begin{array}{ccc}\text { Sample points } \\ \text { af3 }\end{array}$

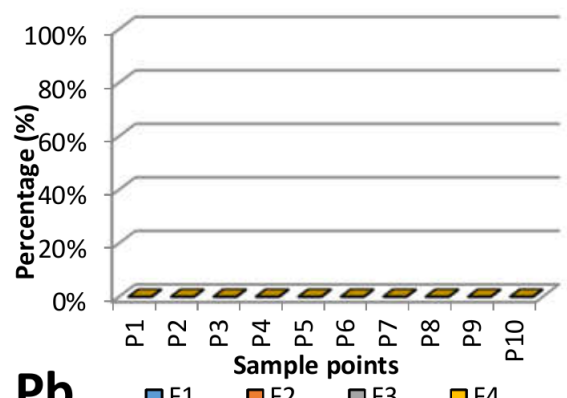

Pb af1 $\begin{gathered}\text { Sample points } \\ \text { PF3 }\end{gathered}$

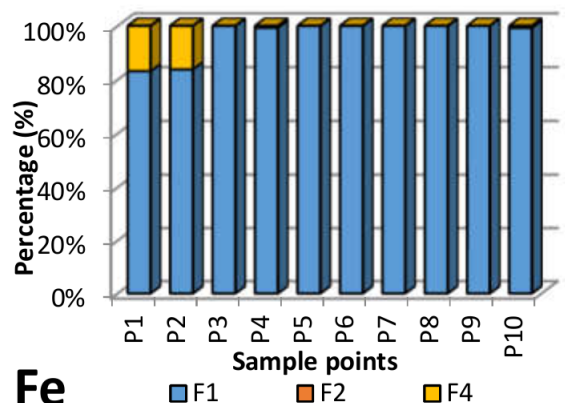

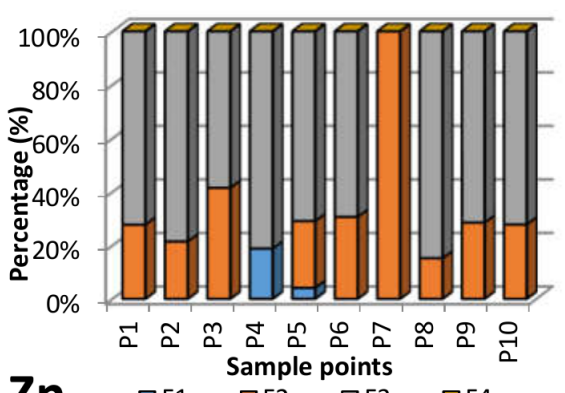

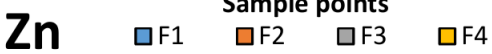

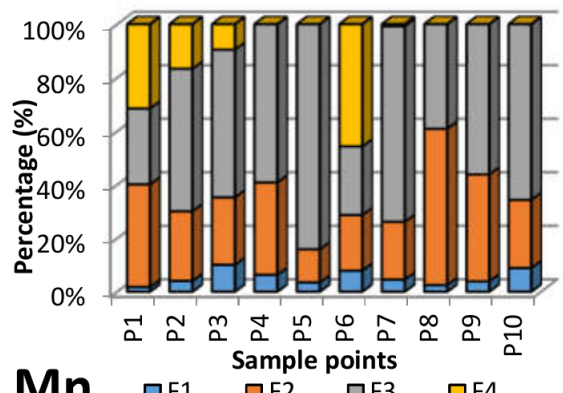

Mn af1 $\begin{array}{cc}\text { Sample points } \\ \square F 3 \quad \square F 4\end{array}$

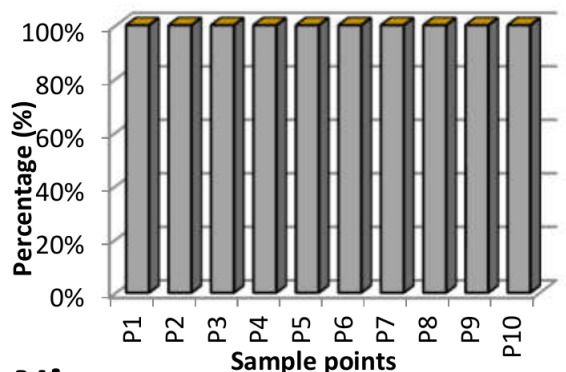

Ni $\quad \begin{array}{llll}\square & \square F 2 & \square F 3 & \square F 4\end{array}$

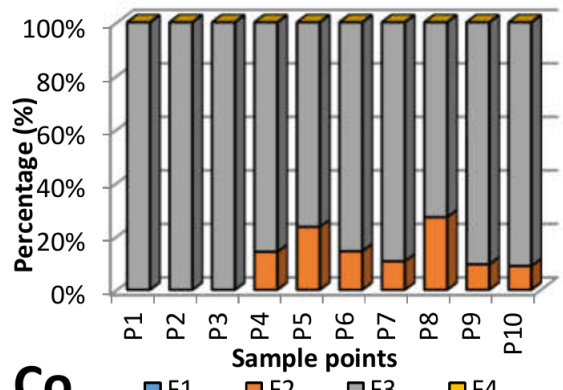

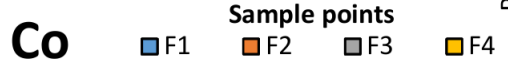

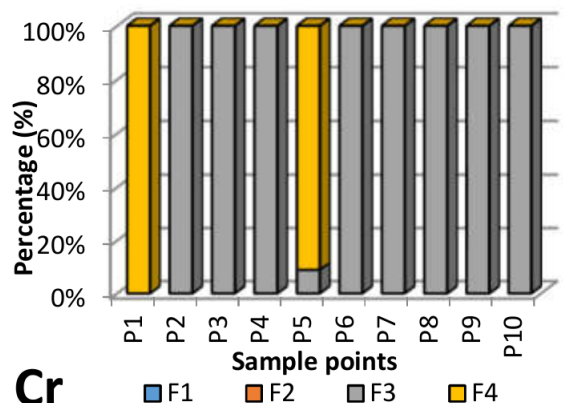

Figure 6. Geochemical distribution of $\mathrm{Cu}$, $\mathrm{Zn}, \mathrm{Ca}, \mathrm{Mn}, \mathrm{Mg}, \mathrm{Ni}, \mathrm{Pb}$, $\mathrm{Co}, \mathrm{Fe}$ and $\mathrm{Cr}$ in the sediment fractions of the Jequiezinho River, collected in March 2018. (F1 = soluble metal; F2 = easily exchangeable metals; F3 = metals bound to carbonates; F4 = metals bound to organic matter). 


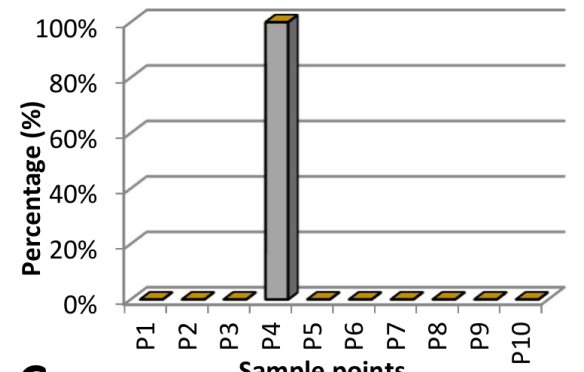

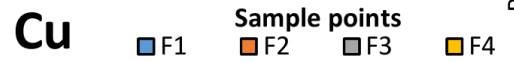

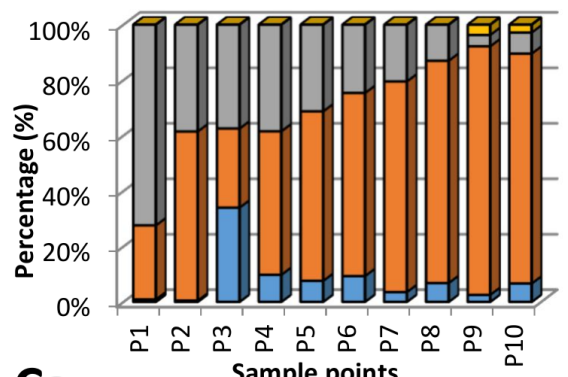

Ca af1 $\begin{array}{ccc}\text { Sample points } \\ \text { Ca }\end{array}$
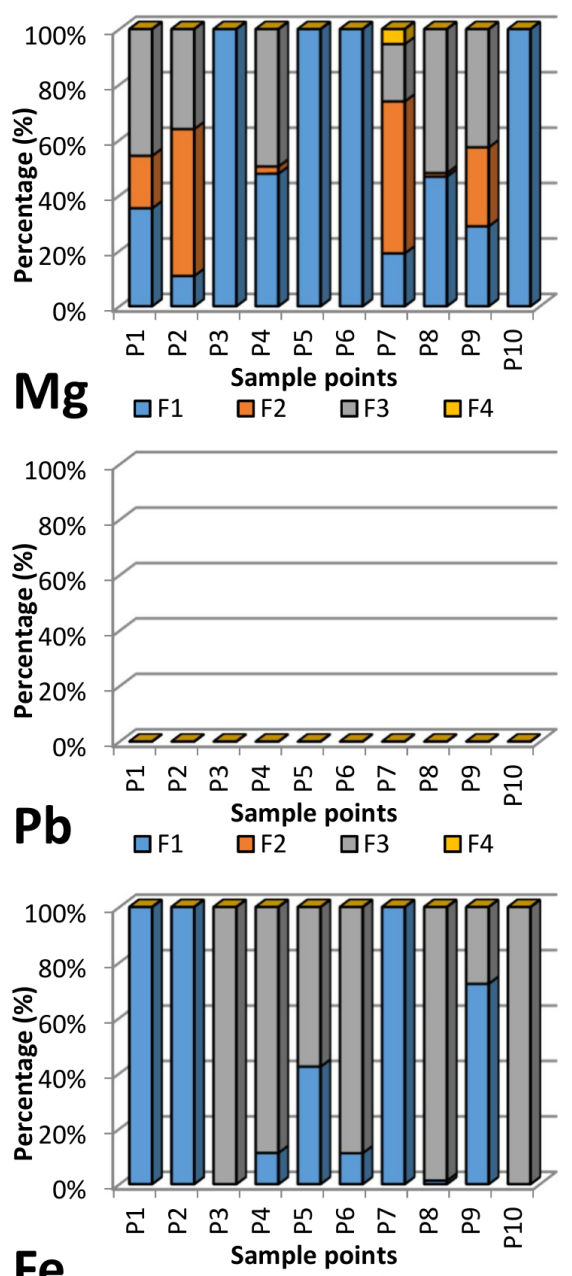

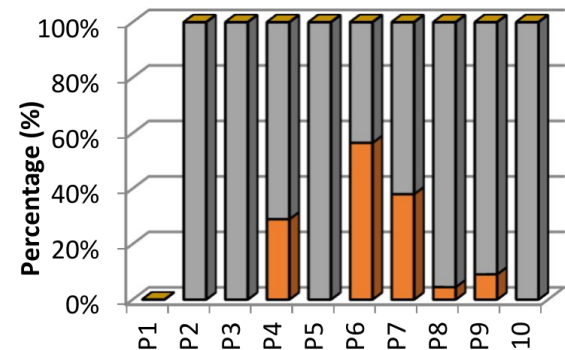

Zn $\quad$ Sample points

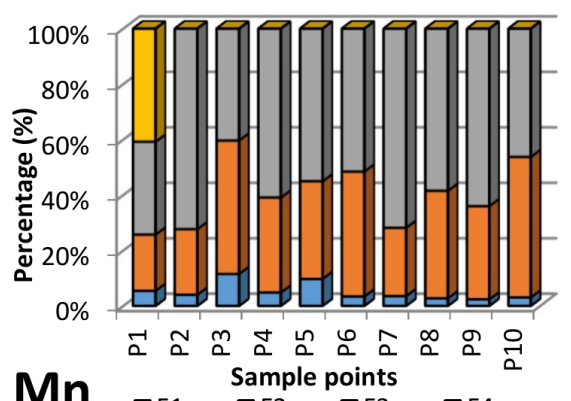

Mn af1 $\begin{gathered}\text { Sample points } \\ \text { GF3 }\end{gathered}$

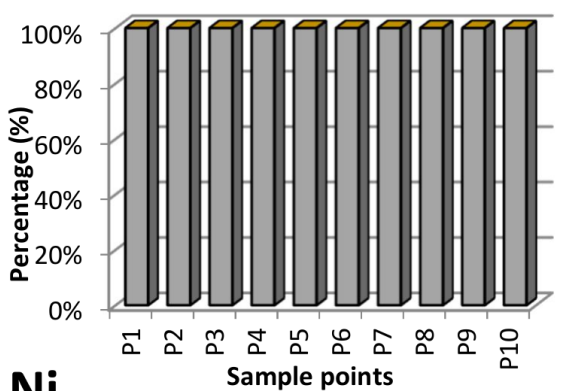

Ni $\quad \begin{array}{lll}\text { Sample points } \\ \square F 2\end{array} \quad \mathrm{~F} 3 \quad \square F 4$

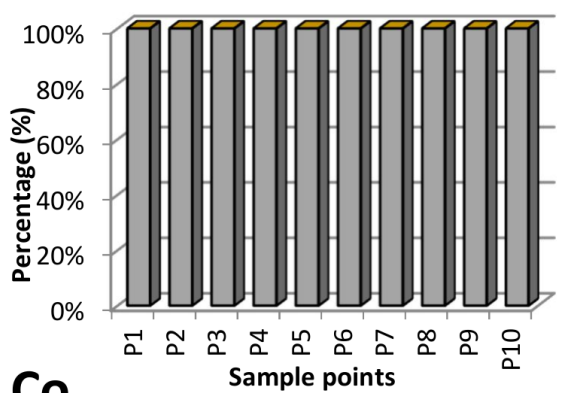

Co af1 $\begin{array}{ccc}\text { Sample points } \\ \square F 2\end{array}$ aF4

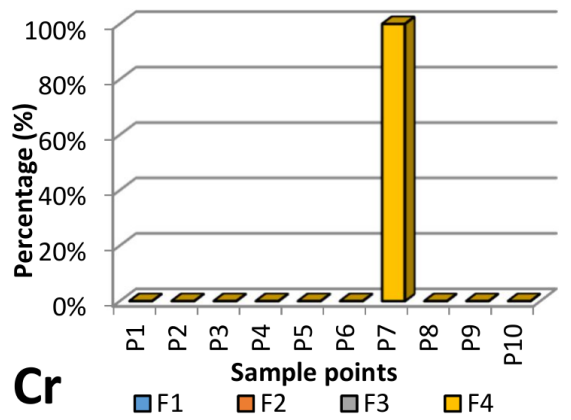

Figure 7. Geochemical distribution of $\mathrm{Cu}$, $\mathrm{Zn}, \mathrm{Ca}, \mathrm{Mn}, \mathrm{Mg}, \mathrm{Ni}, \mathrm{Pb}$, $\mathrm{Co}, \mathrm{Fe}$ and $\mathrm{Cr}$ in the sediment fractions of the Jequiezinho River, collected in September 2018. (F1 = soluble metal; $\mathrm{F} 2$ = easily exchangeable metals; F3 = metals bound to carbonates; $\mathrm{F} 4=$ metals bound to organic matter). 
the most representative from the environmental point of view, since they are the bioavailable part of metals and, when sufficiently high, can cause toxicity to aquatic organisms (Sastre et al. 2001, Brady et al. 2016).

Fractions where the metals could be more easily available in the water column (extracted with water and ammonium acetate) were evaluated through the Mobility Factor (MF) proposed by Kabala \& Singh (2001). This parameter is obtained from the sum of the concentrations obtained in the fractions F1 and F2 divided by the total sum of the sequentially extracted fractions, being expressed in percentage, according to the following equation:

$$
M F=[F 1+F 2 / \Sigma(F 1+F 2+F 3+F 4)] \times 100
$$

The mobility factor for each element analyzed indicates that the metals $\mathrm{Mn}$ and $\mathrm{Mg}$ presented the highest values, followed by $\mathrm{Zn}$ and $\mathrm{Fe}$ in the samples collected at the end of the rainy season. In the dry period, Mg presented the highest value, followed by $\mathrm{Zn}, \mathrm{Mn}, \mathrm{Co}$ and Fe. The mobility order varied seasonally, with $M n>$ $M g>Z n>F e$ at the end of the rainy season and $M g>Z n>M n>C O>F e$ in the dry season (Table VI).

The percentages of metals associated with available fractions suggest that these elements are poorly adsorbed on the sediment surface. It can be easily dissociated from carbonates and made available to the environment, where they can be absorbed by the biological community. This behavior has been noted by other researchers such as Davutluoglu et al. (2011) and Usero et al. (1998) in studies conducted with river or marine sediments.

The occurrence of metals such as $\mathrm{Mn}, \mathrm{Mg}$, $\mathrm{Fe}, \mathrm{Zn}$ and $\mathrm{Co}$ in the available fractions indicates the possible geochemical mobility of these elements in the sediments of the Jequiezinho River, which is not necessarily due to the anthropogenic contributions of the potential emission sources located in the catchment area of the Jequiezinho River. This phenomenon can also be determined by the environmental and geochemical constraints to which the environment is exposed.

The high values of FM can be interpreted as relatively high lability and biological availability of the metals in the sediment (Narwal et al. 1999). This suggests that $\mathrm{Cu}, \mathrm{Pb}, \mathrm{Cu}, \mathrm{Ni}$, and $\mathrm{Cr}$ were not detected in the most labile fractions, but, they were extracted in the pseudo-total digestion and are fixed in the crystalline structure of the stable and resistant weathering mineral silicates and, therefore, are unavailable in the environment (Bevilacqua et al. 2009, Brady et al. 2016).

\section{CONCLUSION}

The results obtained with the pseudo-total digestion of the sediment samples from the Jequiezinho River allowed a quantitative evaluation of the concentration of metals in the environment. The sequential extraction made it possible to observe the phases in which the elements were available, allowing to predict their mobility, as well as their bioavailability to the organisms.

The applied Sediment Quality Values Guidelines (SQVG) indicate that some points present contamination by $\mathrm{Cr}, \mathrm{Ni}, \mathrm{Cu}$ and $\mathrm{Pb}$. However, these metals were not observed in the less stable phases, demonstrating low mobility. The individual mobility factor suggests a greater mobility for $\mathrm{Mg}$ and $\mathrm{Mn}$ and lower for $\mathrm{Zn}, \mathrm{Co}$ and $\mathrm{Fe}$, directly influencing the availability of these elements.

The multivariate statistical analysis revealed that the elements $\mathrm{Cr}, \mathrm{Ni}, \mathrm{Cu}, \mathrm{Co}, \mathrm{Pb}$, and Zn had a similar behavior in the urban portion of the Jequiezinho River, where sewage and other pollutants are discharged, thus reflecting 
Table VI. Comparison of the average mobility (AM) of the extracted metals in the sediments of the Jequiezinho River in relation to the collection period.

\begin{tabular}{|c|c|c|c|c|c|c|c|c|c|}
\hline \multirow{2}{*}{ Collection point } & $\mathrm{Pb}$ & $\mathrm{Cu}$ & $\mathrm{Ni}$ & $\mathrm{Fe}$ & $\mathrm{Cr}$ & Co & Mg & $\mathrm{Zn}$ & $\mathrm{Mn}$ \\
\hline & $\%$ & $\%$ & $\%$ & $\%$ & $\%$ & $\%$ & $\%$ & $\%$ & $\%$ \\
\hline \multicolumn{10}{|c|}{ End of the rainy season } \\
\hline P1 & - & - & - & 1.30 & - & - & 15.97 & - & 14.70 \\
\hline P2 & - & - & - & 0.39 & - & - & 8.48 & - & 9.91 \\
\hline P3 & - & - & - & - & - & - & 70.72 & - & 100.62 \\
\hline P4 & - & - & - & 0.02 & - & - & 10.39 & 11.48 & 32.29 \\
\hline P5 & - & - & - & 0.02 & - & - & 22.40 & - & 5.32 \\
\hline P6 & - & - & - & 0.05 & - & - & 18.33 & 14.29 & 15.64 \\
\hline P7 & - & - & - & 0.02 & - & - & 7.04 & 1.29 & 7.13 \\
\hline P8 & - & - & - & 0.01 & - & - & 5.25 & 1.07 & 16.08 \\
\hline P9 & - & - & - & 0.05 & - & - & 4.28 & 4.61 & 35.14 \\
\hline P10 & - & - & - & 0.00 & - & - & 15.72 & - & 42.22 \\
\hline \multicolumn{10}{|c|}{ Dry season } \\
\hline P1 & - & - & - & 1.22 & - & - & 96.28 & 3.06 & 7.99 \\
\hline P2 & - & - & - & 0.24 & - & - & 54.43 & 2.88 & 4.44 \\
\hline P3 & - & - & - & 0.12 & - & - & 91.30 & 6.02 & 0.77 \\
\hline P4 & - & - & - & 7.00 & - & 15.11 & 79.74 & 3.00 & 3.95 \\
\hline P5 & - & - & - & 0.94 & - & 10.28 & 34.03 & 5.82 & 7.26 \\
\hline P6 & - & - & - & 0.11 & - & 10.59 & 44.84 & 2.93 & 13.41 \\
\hline P7 & - & - & - & 0.35 & - & 7.98 & 22.47 & 17.85 & 4.73 \\
\hline P8 & - & - & - & 0.04 & - & 18.32 & 18.15 & 47.46 & 38.56 \\
\hline P9 & - & - & - & 0.30 & - & 9.05 & 20.53 & 5.92 & 8.88 \\
\hline P10 & - & - & - & 2.78 & - & 6.80 & 33.10 & 2.89 & 2.64 \\
\hline
\end{tabular}

the effects of the anthropogenic contribution. The distribution of the majority elements occurred throughout the study area, especially in isolated sites where there was no evidence of contamination sources, suggesting the geochemical formation of the environment as the most probable source.

\section{Acknowledgments}

The authors would like to acknowledge the financial support of Fundação de Amparo à Pesquisa do Estado da Bahia (FAPESB), Conselho Nacional de Desenvolvimento Científico e Tecnológico, and Financiadora de Estudos e Projetos (FINEP). 


\section{REFERENCES}

ADAMI G, BARBIERI P \& REISENHOFER E. 1999. A comparison on five sediment decomposition procedures for determining anthropogenic trace metal pollution. Int J Environ Anal Chem 75(3): 251-260.

ALAN M \& KARA D. 2019. Comparison of a new sequential extraction method and the BCR sequential extraction method for mobility assessment of elements around boron mines in Turkey. Talanta 194(1): 189-198.

BAIRD C \& CANN M. 2011. Química Ambiental. Porto Alegre: Bookman, $4^{\mathrm{a}}$ ed., $844 \mathrm{p}$.

BARRETO SRG, NOZAKI J, OLIVEIRA E, NASCIMENTO V, ARAGÃO PHA, SCARMINIO IS \& BARRETO WJ. 2004. Comparison of metal analysis in sediments using EDXRF and ICP-OES with the $\mathrm{HCl}$ and Tessier extraction methods. Talanta 62(2): 345-354.

BEVILACQUA JE, DA SILVA IS, LICHTIG J \& MASINI JC. 2009. Extração seletiva de metais pesados em sedimentos de fundo do Rio Tietê, São Paulo. Quim Nova 32(1): 26-33.

BRADY JP, KINAEV I, GOONETILLEKE A \& AYOKO GA. 2016. Comparison of partial extraction reagents for assessing potential bioavailability of heavy metals in sediments. Mar Pollut Bull 106 (1-2): 329-334.

CONAMA - CONSELHO NACIONAL DO MEIO AMBIENTE. 2012. Resolução $n^{\circ}$ 454, de 01 de novembro de 2012. Diário Oficial da União, 17 p.

COPAJA SV, MOLINA X \& TESSADA R. 2014. Determination of heavy metals in Choapa River sediments using BCR sequential extraction procedure. J Chil Chem Soc 59(1): 2353-2358.

CORREIA LO, SIQUEIRA JUNIOR S, CARNEIRO PL \& BEZERRA MA. 2014. Evaluation of the use of Leptodactylus ocellatus (Anura: Leptodactylidae) frog tissues as bioindicator of metal contamination in Contas River, Northeastern Brazil. An Acad Bras Cienc 86: 1549-1561.

DAVUTLUOGLU OI, SECKIN G, ERSU CB, YILMAZ T \& SARI B. 2011. Heavy metal content and distribution in surface sediments of the Seyhan River, Turkey. J Environ Manage 92(9): 2250-2259.

DOS SANTOS JS, DOS SANTOS MJS \& DOS SANTOS MLP. 2009. Parâmetros indicativos do processo de salinização em rios urbanos do semi-árido brasileiro. Quim Nova 32(6): 1534-1538.

DUODU GO, GOONETILLEKE A \& AYOKO GA. 2016. Comparison of pollution indices for the assessment of heavy metal in Brisbane River sediment. Environ Polut 219(1): 1077-1091.
FERNANDES HM. 1997. Heavy metal distribution in sediments and ecological risk assessment: The role of diagenetic processes in reducing metal toxicity in bottom sediments. Environ Polut 97(3): 317-325.

FORNARI A \& BARBOSA JSF. 1994. Litogeoquímica do Batólito Enderbítico-Cranockítico do Complexo Jequié, na região de Laje e Mutuípe, Bahia. Rev Bras Geoc 24(1): 13-21.

FÖRSTNER U. 2004. Traceability of sediment analysis. Trend Anal Chem 23(3): 217-236.

GLEYZES C, TELLIER S \& ASTRUC M. 2002. Fractionation studies of trace elements in contaminated soils and sediments: A review of sequential extraction procedures. TRAC - Trend Anal Chem 21(6-7): 451-467.

GUAN J, WANG J, PAN H, YANG C, QU J, LU N \& YUAN X. 2018. Heavy metals in Yinma River sediment in a major Phaeozems zone, Northeast China: Distribution, chemical fraction, contamination assessment and source apportionment. Sci Rep 8(1): 12231.

HANG X, WANG H, ZHOU J, DU C \& CHEN X. 2009. Characteristics and accumulation of heavy metals in sediments originated from an electroplating plant. J Hazard Mater 163(2-3): 922-930.

KABALA C \& SINGH BR. 2001. Fractionation and mobility of copper, lead and zinc in soil profiles in the vicinity of a copper smelter. J Environ Qual 30(2): 485-492.

KERSTEN M \& FÖRSTNER U. 1989. Speciation of trace elements in sediments. In: Trace element speciation: Analytical methods and problems, BATLEY GE (Ed), CRC Press, Florida, p. 245-317.

KERSTEN M \& FÖRSTNER U. 1995. Speciation of trace metals in sediments and combustion waste. In: URE Am \& DAVIDSON Cm (Eds), Chemical speciation in the environment. Chapman \& Hall, Glasgow, $1^{\text {st }}$ ed., p. 234-275.

LIU C, SHAO S, SHEN Q, FAN C, ZHOU Q, YIN H \& XU F. 2015. Use of multiobjective dredging for remediation of contaminated sediments: a case study of a typical heavily polluted confluence. Environ Sci Pollut Res 22(1): 17839-17849.

MA X, ZUO H, TIAN M, ZHANG L, MENG J, ZHOU X, MIN N, CHANG X \& LIU Y. 2015. Assessment of heavy metals contamination in sediments from three adjacent regions of the Yellow River using metal chemical fractions and multivariate analysis techniques. Chemosphere 144(1): 264-272.

MAGALHÃES PS, SIMÕES NR \& SONODA S. 2016. Limnologia de rios intermitentes: a bacia hidrográfica do rio Jequiezinho como estudo de caso. In: Métodos e técnicas de pesquisa em bacias hidrográficas. $1^{a}$ ed., Ilhéus, BA: Editus, p. 163-181. 
MORILLO J, USERO J \& ROJAS R. 2008. Fractionation of metals and As in sediments from a biosphere reserve (Odiel salt marshes) affected by acidic mine drainage. Environ Monit Assess 139(1-3): 329-337.

NARWAL RP, SINGH BR \& SALBU B. 1999. Association of cadmium, zinc, copper, and nickel with components in naturally heavy metal rich soils studied by parallel and sequential extractions. Commun Soil Sci Plant Anal 30(1): 1209-1230.

PEREIRA JC, GUIMARÃES-SILVA AK, NALINI JÚNIOR HA, SILVA EP \& LENA JC. 2007. Distribuição, fracionamento e mobilidade de elementos traço em sedimentos superficiais. Quim Nova 30(5): 1249-1255.

RELIĆ D, ĐORĐEVIĆ D, POPOVIĆ A, JADRANIN M \& POLIĆ P. 2010. Fractionation and potential mobility of trace metals in Danube alluvial aquifer within an industrialized zone. Environ Monit Assess 171(1-4): 229-248.

RESENDE M, CURI N, REZENDE SB \& CORREA GF. 1995. Pedologia base para distinção de ambientes. $1^{a}$ ed., Viçosa, MG: NEPUT, $304 \mathrm{p}$.

RYAN PC, WALL AJ, HILLIER S \& CLARK L. 2002. Insights into sequential chemical extraction procedures from quantitative XRD: A study of trace metal partitioning in sediments related to frog malformities. Chem Geol 184(3-4): 337-357.

ROSADO D, USERO J \& MORILLO J. 2016. Assessment of heavy metals bioavailability and toxicity toward Vibrio fischeri in sediment of the Huelva estuary. Chemosphere 153(1): 10-17.

SANTOS MJS. 2007. Avaliação espacial e temporal de poluentes no Rio de Contas no município de Jequié Bahia. Brasil, Universidade Estadual do Sudoeste da Bahia. Dissertação de Mestrado.

SASTRE CONDE MI, VICENTE MA \& LOBO MC. 2001. Behavior of cadmium and nickel in a soil amended with sewage sludge. Land Degrad Dev 12(1): 27-33.

WU S, XIA X, LIN C, XI C \& ZHOU C. 2010. Levels of arsenic and heavy metals in the rural soils of Beijing and their changes over the last two decades (1985-2008). J Hazard Mater 179(1-3): 860-868.

SILVA MLS. 2006. Avaliação do comportamento de elementos traço essenciais e não essenciais em solo contaminado sob cultivo de plantas. Tese de Doutorado. Escola Superior de Agricultura Luiz de Queiroz, USP, Piracicaba.

SOARES HM, BOAVENTURA RA, MACHADO AA \& ESTEVES DA SILVA JC. 1999. Sediments as monitors of heavy metal contamination in the Ave river basin (Portugal): Multivariate analysis of data. Environ Pollut 105(3): 311-323.

TEIXEIRA EC, RODRIGUES MLK, ALVES MFC \& BARBOSA JR. 2003. Study of geochemical distribution of heavy metals in sediments in areas impacted by coal mining', In: LOCAT J, GALVEZ-CLOUTIER R, CHANEY RC \& DEMARS K (Eds), Contaminated Sediments: Characterization, Evaluation, Mitigation/Restoration, and Management Strategy Performance, ASTM STP 1442, ASTM International, West Conshohocken, PA, USA, p. 72-86.

TESSIER A, CAMPBELL PGC \& BISSON M. 1979. Sequential Extraction Procedure for the Speciation of Particulate Trace Metals. Anal Chem 51(7): 844-851.

TURNER A \& TAYLOR A. 2018. On site determination of trace metals in estuarine sediments by field-portable-XRF. Talanta 190(1): 498-506.

UNGUREANU T, IANCU GO, PINTILEI M \& CHICOS MM. 2016. Spatial distribution and geochemistry of heavy metals in soils: a case study from the NE area of Vaslui county, Romania. J Geochem Explor 176(1): 20-32.

URE AM, QUEVAUVILLER PH, MUNTAU H \& GRIEPINK B. 1993. Speciation of heavy metals in soils and sediments: An account of the improvement and harmonization of extraction techniques undertaken under the auspices of the BCR of the Commission of the European Communities. Int J Environ Anal Chem 51(1-4): 135-151.

USERO J, GAMERO M, MORILLO I \& GRACIA I. 1998. Comparative study of three sequential extraction procedures for metals in marine sediments. Environ Int 24(4): 487-496.

VAREDA PJ, VALENTE AJM \& DURÃES L. 2019. Assessment of heavy metal pollution from anthropogenic activities and remediation strategies: a review. J Environ Manage 246(1): 101-118.

ZHANG Z, JUYING L, MAMAT Z \& QINGFU Y. 2016. Sources identification and pollution evaluation of heavy metals in the surface sediments of Bortala River, Northwest China. Ecotox Environ Safe 126(1): 94-101.

WIJESIRI B, LIU A, DEILAMI K, HE B, HONG N, YANG B, ZHAO X, AYOKO G \& GOONETILLEKE A. 2019. Nutrients and metals interactions between water and sediment phases: An urban river case study. Environ Pollut 251(1): 354-362.

\section{How to cite}

SILVA DS, CERQUEIRA UMFM, AGUIAR RM, CARNEIRO PLS \& BEZERRA MA. 2020. Characterization, fractionation and mobility of trace elements in surface sediments of the jequiezinho river, Bahia, Brazil. An Acad Bras Cienc 92: e20190558. DOI 10.1590/0001-3765202020190558. 
Manuscript received on May 18, 2019;

accepted for publication on October 4, 2019

DARCI S. SILVA ${ }^{1}$

http://orcid.org/0000-0001-9711-3236

UILLIAM M.F.M. CERQUEIRA ${ }^{2}$

http://orcid.org/0000-0002-2158-379X

ROSANE M. AGUIAR ${ }^{2}$

http://orcid.org/0000-0002-9803-8183

PAULO LUIS S. CARNEIRO ${ }^{1}$

http://orcid.org/0000-0001-7708-6197

MARCOS A. BEZERRA ${ }^{2}$

http://orcid.org/0000-0003-2933-893X

${ }^{1}$ Universidade Estadual do Sudoeste da Bahia,

Departamento de Ciências Biológicas, Av. José Moreira

Sobrinho, s/n, 45206-191 Jequié, Bahia, Brazil

${ }^{2}$ Universidade Estadual do Sudoeste da Bahia,

Departamento de Ciências e Tecnologia, Av. José Moreira

Sobrinho, s/n, 45206-191 Jequié, Bahia, Brazil.

Correspondence to: Marcos de Almeida Bezerra

E-mail:mbezerra@uesb.edu.br

\section{Authors contributions}

Darci Santos Silva, Rosane Moura Aguiar and Marcos Almeida Bezerra conceived the research that originated this manuscript. Darci Santos Silva and Uilliam Mozart Ferreira da Mata Cerqueira carried out the laboratorial experiments and applied the analytical methods. Darci Santos Silva, Rosane Moura Aguiar, Paulo Luis Souza Carneiro and Marcos Almeida Bezerra contributed in the statistical analysis. All authors discussed the results and contributed to write the final manuscript.

\section{(cc) BY}

